\title{
NOTES ON THE PYCNOGONIDA OF PLYMOUTH
}

\author{
By Marie V. Lebour, D.Sc. \\ Naturalist at the Plymouth Laboratory
}

(Text-figs. I-7)

The Pycnogonida of Plymouth have had very little attention and early records are few. Of the eight species recorded in the Plymouth Marine Invertebrate Fauna in 1904, two, Nymphon gallicum and N. gracile, are synonymous, and these two are also recorded in the I93I edition which comprises only the same eight species. The scarcity of the records shows that little search was made for the members of this group, for on revising it at the present time it is found that thirteen species certainly occur, being five more than are shown in the Marine Invertebrate Fauna. Hodgson (I9I0) records thirteen species from Devonshire, but these are not all the same as the thirteen now recorded. He mentions eleven from Plymouth, three of which have not been found recently. These are Pallene spectrum, Nymphon brevirostre and Ammothea laevis.

The species recorded in the Plymouth Marine Fauna (1904, 1931) are:

Pycnogonum littorale Ström

Endeis spinosus (Montagu)

Anaplodactylus petiolatus (Krøyer)

Pallene brevirostris Johnston
Nymphon gracile Leach (with N. gallicum Hoek)

N. rubrum Hodge

Ammothea echinata (Hodge)

The species recorded by Hodgson (I9I0) from Devonshire are:

$\begin{array}{ll}\text { Pycnogonum littorale (Ström) } & \text { Pallene brevirostris Johnston } \\ \text { Endeis spinosus (Montagu) } & \text { P. spectrum Dohrn } \\ \text { Phoxichilidium femoratum (Rathke) (from } & \text { Nymphon rubrum Hodge } \\ \text { south coast of Devonshire and Star- } & \text { N. brevirostre Hodge } \\ \text { cross only) } & \text { N. gracile Leach } \\ \text { Anaphia (=Anoplodactylus) petiolata } & \text { Achelia (=Ammothea) echinata Hodge } \\ \text { (Krøyer) } & \text { A. laevis Hodge } \\ \text { A. virescens (Hodge) } & \text { A. hispida Hodge }\end{array}$

Of these Phoxichilidium femoratum proper has not been found by me at Plymouth, although it must occur, for a specimen sent to me from the Dundee collection, kindly lent by Dr Calman, is labelled Plymouth. On the other hand, I find that a second species (almost certainly the P. femoratum of Hoek (I88I) and of Loman (I907) from Holland) is common at Plymouth in certain localities and also occurs at Millport in the west of Scotland. There is little doubt that this species has been confused with $P$. femoratum. Sars (189I) has already suggested that Hoek's species was distinct, but the hint has not hitherto been followed up. 
$P$. virescens was first found by Hodge at Polperro, Cornwall. It is usually regarded nowadays as an Anoplodactylus, but it clearly has a five-segmented oviger and, following most modern authorities, this shows it to be a Phoxichilidium. It is now found to be common between tide-marks in certain localities round Plymouth:

Pallene spectrum has only been found by Norman (1908). No details, except Plymouth as locality, are available.

Nymphon brevirostre, according to Hodgson (I9IO), has been found at Plymouth, but I have not seen it. Apparently it was taken at Plymouth and also at Starcross by Norman (1908).

In addition to these I have to add Anoplodactylus angulatus (Dohrn) to the British fauna. This species is very like Phoxichilidium virescens, but the oviger is composed of six segments.

Anoplodactylus pygmaeus, the Pallene pygmaeus of Hodge, is here shown to be identical with Dohrn's Phoxichilidium exiguum.

The following is a list of species seen by myself at Plymouth from inshore waters during the last three years:

Pycnogonum littorale Ström

Endeis spinosus (Montagu)

Phoxichilidium tubulariae n.sp.

$P$. virescens Hodge

Anoplodactylus angulatus (Dohrn)

$A$. petiolatus (Krøyer)

A. pygmaeus (Hodge) $=$ Phoxichilidium exiguum Dohrn
Pallene brevirostris Johnston Nymphon gracile Leach N. rubrum Hodge Ammothea echinata (Hodge) A. longipes (Hodge) $=$ hispida Hodge

In addition, Phoxichilidium femoratum is recorded from south Devon by Norman (1908), and, as is mentioned above, a specimen from Plymouth is in the Dundee collection, although I have not found it myself. If Pallene spectrum, Nymphon brevirostris and Ammothea laevis are added to this list, we have sixteen species, exactly double the number recorded in the fauna lists. These include a new species and a new British record. The fact that all the first twelve of these have been collected in very shallow waters in restricted areas close to the shore makes it likely that others will be found when facilities for collection in deeper waters are available.

My best thanks are due to Dr I. Gordon of the British Museum for allowing me to examine certain specimens from the Norman Collection, to Dr W. T. Calman for sending me a collection from Dundee, to Mr R. Elmhirst for much help in collecting specimens, to Prof. Hobson for sending specimens of Phoxichilidium femoratum from the Northumberland coast, to Miss E. Clay of the Plymouth Laboratory, who in her work with Dr M. Parke on seaweeds discovered a fertile field for pycnogonids at the bases of the thalli of Ascophyllum at Wembury, and to Dr Vera Fretter of the Royal Holloway College for collections from Kingsand.

The Ascophyllum from Church Reefs, Wembury, had short Sertularia growing on them near the base, and here were found many specimens of 
Phoxichilidium virescens, Anoplodactylus angulatus and Ammothea echinata. These also occurred in the rock pools amongst corallines as they did in similar situations at Kingsand.

At Wembury Phoxichilidium virescens and Anoplodactylus angulatus were found spread out on the thallus of the Ascophyllum and were almost exactly the same colour. Most of them were also striped with purple, and this was accentuated in those from the corallines. It is interssting that Colman in his research at Wembury on the faunas inhabiting intertidal seaweeds (I940), specially notes that he found very few pycnogonids on Ascophyllum. The reason seems to be that he worked in an area which was not so fertile for the weed as that worked by Miss Parke and Miss Clay, although they were not far apart.

Another very good locality was found by $\mathrm{Mr}$ William Searle at the sides of Phoenix Wharf. Large tufts of the bryozoan Bowerbankia obtained from scrapings were found to be full of Anoplodactylus pygmaeus and dredgings from the Laira yielded tangles of weed, bryozoans and hydroids in which $A$. petiolatus as well as $A$. pygmaeus was found. Ammothea echinata and $A$. longipes occurred also in both localities as well as at Wembury.

Phoxichilidium tubulariae n.sp., also found at Millport, must have been confused for long with $P$. femoratum. It occurs almost exclusively on Tubularia larynx, especially on those growing on the experimental raft moored near the Plymouth Breakwater. It has also been found on the Millbay Pontoon. Nymphon rubrum and $N$. gracile are fairly common between tide-marks at Wembury and at Kingsand and are also taken in the Cattewater and at Millbay. As dredgings from the Sound were unobtainable in these years of the war, the above-mentioned localities were used almost exclusively.

\section{ColOuR}

The colour of the species is usually very characteristic, but it may vary to a large degree. Phoxichilidium femoratum is always red, usually a deep red. P. tubulariae n.sp., is usually colourless or pale yellowish and sometimes a sepia-brown; sometimes it is red or brown at the joints. Nymphon rubrum is red, whilst N. gracilis is colourless, yellowish or pink. Endeis spinosus may be colourless or yellowish, but sometimes has deep purple lines at the joints and the intestinal fluid may be a deep purple. Anoplodactylus angulatus is usually greenish with deep purple bands across the body and limbs and the intestinal fluid is green. Young specimens may be quite colourless. Phoxichilidium virescens is usually the same colour as Anoplodactylus angulatus, greenish with purple bands, the intestinal fluid being green. These two species often occur together. It is probable that $A$. angulatus has hitherto been confused with Phoxichilidium virescens.

I have not yet succeeded in correlating the colour of the intestinal fluid with any particular food or habitat, except in the young of $P$. tubulariae which live inside the gastral cavity of the hydroid and have the intestinal 
fluid of the same colour. As mentioned above $P$. virescens and Anoplodactylus angulatus closely approximate in colour to that of the Ascophyllum and the purple bands are like the corallines. It is interesting to find that varieties of other species occur with similar dark purple bands, and that these usually live among corallines or Bowerbankia. Thus on the tufts of Bowerbankia from Phoenix Wharf and from the Laira dredgings specimens of Anoplodactylus pygmaeus with deep purple bands were fairly frequent along with the pale coloured individuals in the proportion of about one in twenty. One specimen of $A$. petiolatus out of ten had a similar colouring, and one Ammothea echinata out of many. These pycnogons were frequently found in the autumn months when most hydroids had died down. Sertularia, however, in very short colonies was alive at this season, and, occasionally, small colonies of Obelia. It is difficult to be certain of the food in many cases, but Phoxichilidium tubulariae could easily be seen to eat the Tubularia on which it lives.

\section{BREEDING}

Most pycnogonids breed in spring and summer, but in addition to the usual breeding season males bearing eggs of Anoplodactylus angulatus and Phoxichilidium virescens were frequently found in autumn and winter, also, occasionally Anoplodactylus pygmaeus and Phoxichilidium tubulariae in autumn. Endeis spinosus occurred with eggs in January 1945. Nymphon rubrum was found with eggs early in March and others have been recorded in February. The growth of the hydroids is probably the chief factor of importance in the breeding. Larval Ammothea (almost certainly A. echinata) occur plentifully among Obelia in the summer.

It is chiefly in the family Phoxichilidiidae that the most interesting breeding habits occur. In this family the larvae live parasitically in the coelenterates. It has been shown (Lebour, I9I7) that the larvae of Anoplodactylus petiolatus (=Anaphia petiolata) develop in the manubrium of medusae of Obelia and certain other related forms. Dogiel (I9I3), in his fine work on larval pycnogonids, states that the larvae of this species form galls on the hydroid Syncoryne eximia in the same way that Phoxichilidium femoratum does. As will be shown below it is now almost certain that the species on which Dogiel worked at Millport is not Anoplodactylus petiolatus but Phoxichilidium virescens. His Anoplodactylus pygmaeus, the larva of which occurs in Obelia hydroids, has been found in exactly the same habitat at Plymouth. The larvae of Anoplodactylus petiolatus (not of Dogiel) and of $A$. pygmaeus are much alike, both occurring in Obelia, but one in the medusa and the other in the hydroid. There is no doubt that they are separate species, although in my former work (19I7) they were regarded as identical. Dogiel notes that the larva in Syncoryne is much more like Phoxichilidium femoratum than it is like Anoplodactylus pygmaeus, and his figures show that it is almost certainly Phoxichilidium virescens. The breeding of Anoplodactylus angulatus is not yet known, although 
its usual habitat on or near Sertularia seems to point to that hydroid as the host for the larva. It is hoped to prove this later on.

We thus have the British species of the Phoxichilidiidae with distinctive breeding habits and larval hosts as follows:

Species

Phoxichilidium femoratum

P. tubulariae n.sp.

P. virescens

Anoplodactylus petiolatus

A. pygmaeus

A. angulatus
Host

Syncoryne eximia, in cysts (Hodge, 1863 ; Dogiel, I913)

Tubularia larynx, in gastral cavity (Loman, 1907; Lebour, in the present work)

Syncoryne eximia, in cysts (Dogiel, I9I3)

Obelia medusa and related forms, in manubrium (Lebour, I917)

Obelia hydroid, in gastral cavity (Dogiel, I913; Lebour, in the present work)

Unknown, but possibly Sertularia

Numerous authors have described larvae of Phoxichilidiidae, but in most cases it is difficult to be certain about the identification of the species: detailed references are therefore omitted.

\section{Notes ON THE SPECIES}

A list of the Plymouth species is given below with any notes that are relevant. The Phoxichilidiidae have been dealt with much more fully than the others, as certain important points have been discovered and with some of them changes in nomenclature have been found necessary. The new species Phoxichilidium tubulariae is described and compared with $P$. femoratum. $P$. virescens is removed from Anoplodactylus to Phoxichilidium; Anoplodactylus pygmaeus (Hodge) has been identified as synonymous with Phoxichilidium exiguum Dohrn, and Anoplodactylus angulatus has been added to the British fauna.

\section{Family NYMPHONIDAE \\ Genus Nymphon Fabricius \\ Nymphon gracile Leach}

Norman (I908) has shown that N. gallicum Hoek is the same species. Common between tide-marks and dredged in the Sound. For separate records see Plymouth Marine Fauna (I93I). Breeding in February, May and Jure and probably throughout spring and summer.

A shore and shallow-water species, its distribution ranging from Denmark to the Mediterranean.

\section{Nymphon rubrum Hodge}

Common between tide-marks: Wembury, Millbay Pontoon, Kingsand; also dredged in the Sound. Breeding in spring (including March) and summer. 
A shore and shallow-water species, its distribution ranging from Norway and Sweden to Holland and Belgium. On all the English coasts, Scotland and Ireland.

\section{Nymphon brevirostre Hodge}

Recorded by Norman (I908) and.Hodgson (I910) from Plymouth Sound, Yealm River and Starcross. Not found within recent years.

A very small species, littoral to about $60 \mathrm{~m}$. depth. Ranging from Norway and Sweden to the south of England.

\section{Family PALLENIDAE \\ Genus Pallene Johnston \\ Pallene brevirostris Johnston}

Not uncommon between tide-marks and dredged in the Sound. For separate records see Plymouth Marine Fauna (193I). Found recently in plankton from the Laira and between tide-marks among corallines, Wembury. Crawshay (I9I2) found a specimen 46 miles south-west of the Eddystone, in $49 \mathrm{fm}$. It occurs from the coast to fairly deep water.

Distribution ranging from Denmark, Norway and Sweden, Kiel and Naples to the Atlantic coast of north-east America.

\section{Pallene spectrum Dohrn}

Norman (I908) records this species from Plymouth. No data are available. Recorded elsewhere only from Naples.

\section{Family PHOXICHILIDIIDAE}

In the British representatives of this family the palpi are always absent, and in all the species the ovigerous legs are present only in the male. The family includes some of the most puzzling species in the British fauna and is also specially interesting because the larvae are adapted for parasitizing hydroids.

Three genera are British, but only two are common and recorded from Plymouth-Phoxichilidium and Anoplodactylus. Wilson (I878) founded the genus Anoplodactylus, separating it from Phoxichilidium by the number of segments in the ovigers (six in Anoplodactylus, five in Phoxichilidium) and by the (so-called) absence of auxiliary claws on the dactylus. The latter character, however, does not hold good, as Sars (I89I) has already noted, for some Anoplodactylus, including $A$. petiolatus which Wilson himself refers to the genus, have small auxiliary claws quite as much developed as in some Phoxichilidium (for example, $P$. virescens).

Although the genus Anoplodactylus is recognized by most modern workers, it comes very close to Phoxichilidium, and except by the ovigers it is difficult to separate them. It is only in deference to these workers that I have kept them apart and because of the great increase in the number of species which makes the division convenient. Personally I do not think that the division 
is a natural one. Marcus (1940), dealing with this family, does not make things easier by disregarding the segmentation of the ovigers in the genus Phoxichilidium. In this genus he places Dohrn's $P$. exiguum, which is shown here to be synonymous with Anoplodactylus pygmaeus and is clearly closely related to $A$. petiolatus. Although he places Phoxichilidium virescens, rightly, in this genus he is evidently following Hoek, who apparently really had Anoplodactylus angulatus which is a true Anoplodactylus. However, he places in the genus Halosoma of Cole (1904) Dohrn's Phoxichilidium robustum, which is shown below to be so close to $P$. virescens that it is impossible to place them in different genera. Helfer \& Schlottke (1935) place Anoplodactylus exiguus in the genus Halosoma and Anoplodactylus pygmaeus in Anoplodactylus, and these two species are obviously identical. Norman (1894, I908) regarded $A$. pygmaeus and $A$. exiguus as synonymous with $A$. petiolatus. The explanation here is that he, among many workers, regarded Hoek's (I88I) Phoxichilidium pygmaeus as the same as Hodge's species, whereas Hoek's species is certainly Anoplodactylus petiolatus, as can be seen from his figures. Norman is right in regarding Hoek's pygmaeus as synonymous with $A$. petiolatus but wrong in regarding $A$. exiguus as synonymous with that species. Bouvier (1923) regarded Phoxichilidium virescens and $P$. robustum as Anoplodactylus and $A$. petiolatus, $A$. pygmaeus and $A$. exiguus as distinct species. Like Norman, he was describing Hoek's pygmaeus. The matter is discussed further under the separate species.

It is shown here that there are two species hitherto included under the name Phoxichilidium femoratum, one of which must be given a new name, and for this $P$. tubulariae is proposed from its invariable habit of breeding inside the hydroids of Tubularia larynx. This is the species whose life history is described by Loman (1907) from Herdla as Phoxichilidium femoratum, and also, almost certainly, the P. femoratum of Hoek (I88I) also from Herdla. It is to be noted once more that Sars (I89I) had already queried the identity of Hoek's species, thinking it was probably different from $P$. femoratum and giving as his chief reason the armature of the propodus as described below. He regarded $P$. femoratum as a truly northern species, and probably Plymouth is almost its southern limit.

There are six species in the Plymouth area belonging to the Phoxichilidiidae, and they form three groups of two each:

(I) Phoxichilidium femoratum and P. tubulariae. These may be regarded as Phoxichilidium proper, having an elongated form, five segments in the oviger, short cephalon, and short ocular process, auxiliary claws placed dorsally and well developed, cement glands not opening in a funnel but in a series of depressions on the femur, or hardly raised from the surface. There are no tubercles on the lateral processes and no cutting lamella on the propodus.

(II) At the other extreme comes Anoplodactylus proper represented by $A$. petiolatus and $A$. pygmaeus (=exiguus) with six segments in the oviger, 
long or short cephalon with long ocular process, auxiliary claws short and placed laterally $(A$. petiolatus) or absent (A.pygmaeus), cement glands opening in a funnel on the femur. There are dorsal tubercles on the lateral processes and a cutting lamella on the propodus.

(III) Joining these two groups in the British species come Phoxichilidium virescens, so closely related to $P$. robustum that they might be forms of the same species, and Anoplodactylus angulatus, having five and six segments respectively in the oviger. Otherwise they are extremely alike and come nearer to Phoxichilidium than to Anoplodactylus, having a short cephalon and short ocular process, cement glands not opening in a funnel but in small openings along the dorsal surface of the femur, no lamellae on the propodus and no protuberances on the lateral processes. Unlike Phoxichilidium, however, they have small auxiliary claws placed laterally as in Anoplodactylus petiolatus.

Foreign species do not fall so readily into these groups. Phoxichilidium australe Hodgson (see Calman, 1915) is very like P. virescens, Anoplodactylus cribellatus Calman and A. investigatorius Calman (1923) come close to A. angulatus, but $A$. saxatilis Calman has a femoral gland tube, no lamina on the propodus and no protuberances on the lateral processes, thus coming between $A$. angulatus and $A$. petiolatus; an unnamed species from Burma (Calman, 1923) closely resembles $A$. petiolatus, but has no tubercles on the lateral processes. These are only a few examples of the variability of the species in the family which appear to be altering in countless directions. If it were not for the ever-growing number, it would perhaps be best to keep them all in one genus.

\section{Genus Phoxichilidium Milne-Edwards Phoxichilidium femoratum (Rathke)}

(Figs. I $a-c, 2 a$ )

This is the common northern species and well known since the time of Rathke. It is the species recorded by all the Scandinavian workers and occurs in Britain on all our coasts. Its larval stages are described by Hodge (I86I) from the coast of Durham, in Coryne (= Syncoryne eximia). Later these were again described by Dogiel (I9I3) from Millport. The species is a dark and brilliant red which colours the whole cuticle. The description of Sars (I89I) with figures cannot be bettered and his figures have been copied by most workers. It has been recorded from Starcross, Devon, and a specimen labelled 'Plymouth' occurs in the Dundee collection. I have not yet succeeded in finding it in the Plymouth area, although Phoxichilidium tubulariae is abundant. Both species are to be found at Millport, one chiefly on Syncoryne and the other on Tubularia. I am very grateful to Mr Elmhirst for information on this point and for specimens of both species. 
Phoxichilidium tubulariae n.sp.

(Figs. I $d-g, 2 b, 3 a-c$ )

Phoxichilidium femoratum (Rathke) Hoek, I88I.

Phoxichilidium femoratum (Rathke) Loman, 1907.

? Phoxichilidium femoratum (Rathke) Schlottke, I932.

This species occurs at Plymouth in numbers among Tubularia larynx, especially where it grows on the experimental raft moored near the Breakwater and also on the Millbay pontoon. It is usually almost colourless or
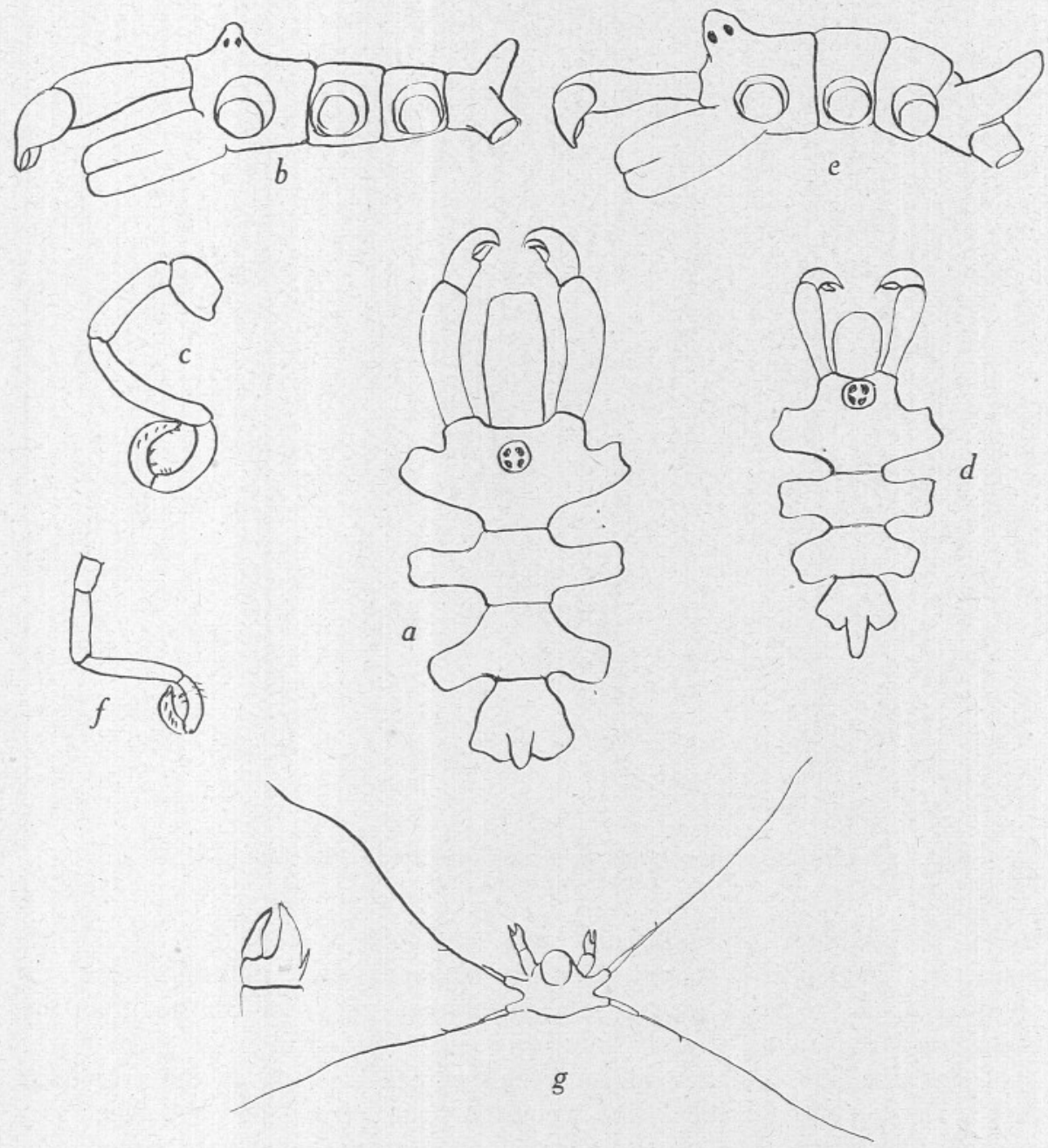

Fig. I. $a-c$, Phoxichilidium femoratum: $a$, dorsal view $\rho$; $b$, side view; $c$, oviger of $\hat{o} . d-g$, Phoxichilidium tubulariae: $d$, dorsal view; $e$, side view; $f$, oviger of $o ; g$, newly hatched larva. 
a pale straw colour, occasionally having red lines on the body sutures. It may also be brownish to sepia-brown. It may easily be seen eating the Tubularia heads, and its young are found in the gastral cavity of the hydroid. It is smaller and more slender in build than Phoxichilidium femoratum, its proboscis more or less swollen anteriorly and shorter in proportion to the body. The processes of the last abdominal segment are shorter and the abdomen longer. The body is about $1.5 \mathrm{~mm}$. in length. The segmentation is distinct. The
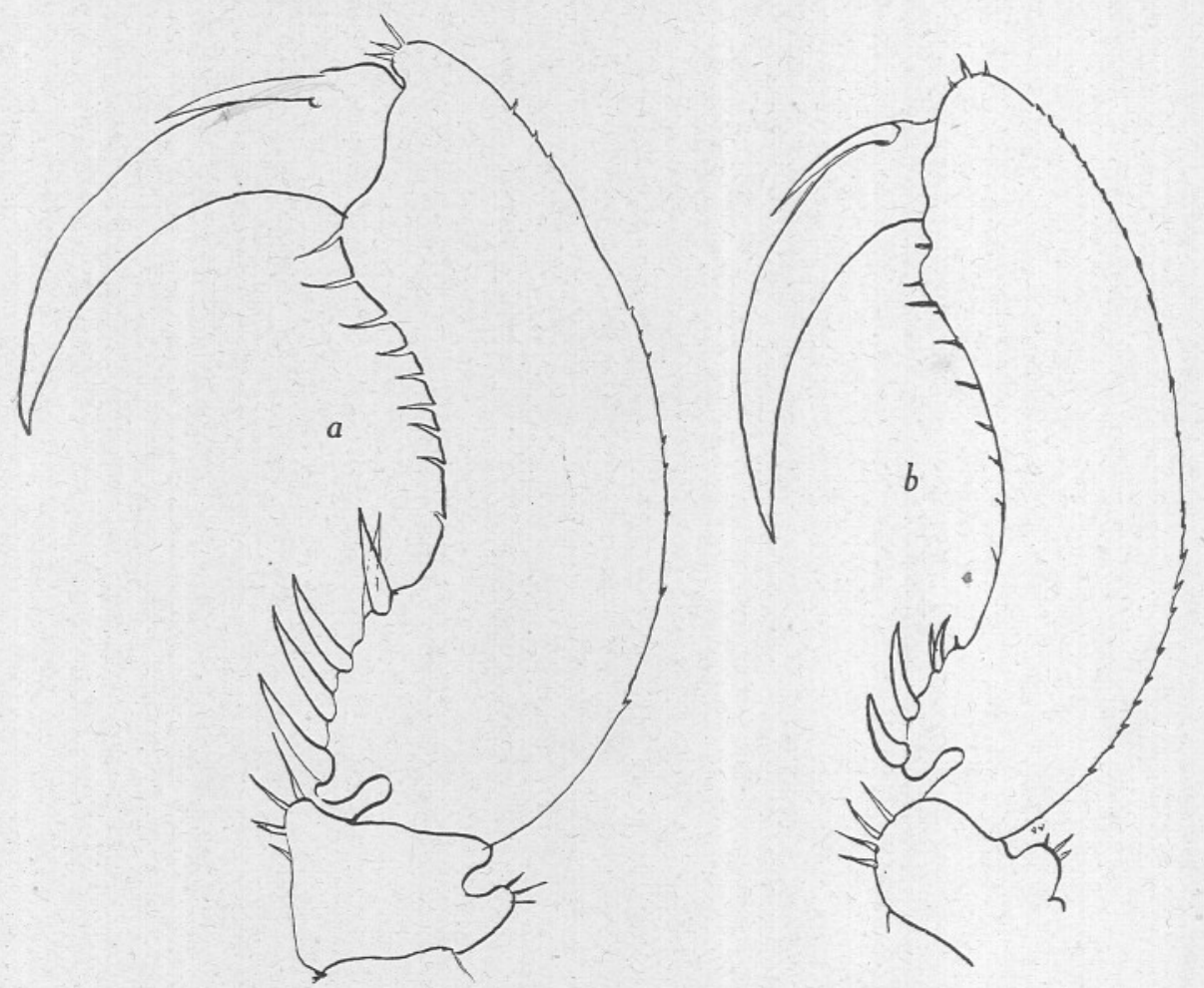

Fig. 2. $a$, Phoxichilidium femoratum, propodus and claw; $b$, Phoxichilidium tubulariae, propodus and claw.

lateral processes are very distinct and separated by less than their own diameter. The cephalon is very short, the ocular tubercle blunt and reaching obliquely over the front margin. The proboscis is distinctly shorter than the chelophore, expanding slightly anteriorly and rounded in front. The oviger is of five distinct segments, the terminal segment as long as the preceding with a few recurved spines. The second coxa is longer than the other two together, the femur and tibiae subequal. The armature of the propodus is of the same type as in $P$. femoratum, but with fewer teeth at the base of the sole, usually two large teeth, followed by a pair slightly smaller. The auxiliary 
claws are large and placed dorsally. Cement glands open on very inconspicuous pores placed dorsally on the femur.

A comparison of the two species is given below, showing the main points of difference:

\section{Phoxichilidium femoratum}

Length of body $c a$. $1 \cdot 9-2 \mathrm{~mm}$. Proboscis cylindrical, almost the same width throughout, end almost straight

Abdomen about the same length as the posterior abdominal processes

First two lateral processes with oblong spaces larger than the width of the processes themselves

Propodus usually armed at base with three or four large single and one pair of usually smaller teeth, number slightly variable

Colour red

Larvae in cysts in Syncoryne eximia

\section{Phoxichilidium tubulariae}

Length of body $c a$. I $\cdot 4-\mathrm{I} \cdot 5 \mathrm{~mm}$. Proboscis wider anteriorly, shorter than in $P$. femoratum, end rounded, considerably shorter than the basal seg-. ment of the chelophores

Abdomen nearly twice as long as the posterior abdominal processes

Lateral processes with spaces narrower than the width of the processes themselves

Propodus armed at base with two large single and one smaller pair of teeth, number slightly variable

Colourless or straw colour, rarely brown or with red at sutures

Larvae in Tubularia, in gastral cavity

The larvae of $P$. femoratum have been described by Hodge (1864) and by Dogiel (1913). They occur on Syncoryne eximia where they cause the hydroid
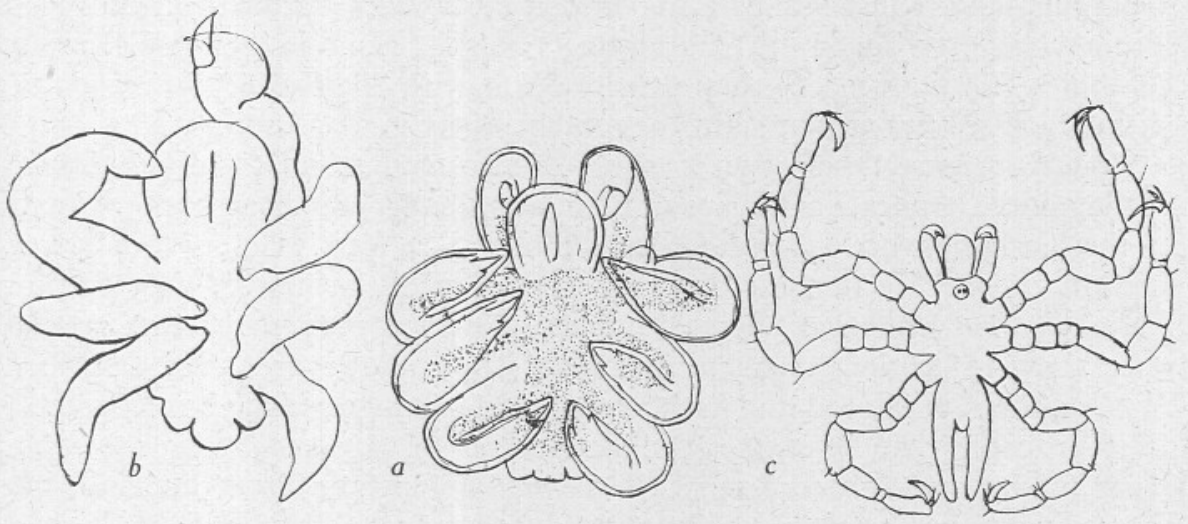

Fig. 3. Phoxichilidium tubulariae. a, penultimate larva from Tubularia; $b$, cast skin of same; $c$, last larva from cast skin. (About one-third scale of $a$ and $b$.)

to form cysts round them. Loman (1907) has found the larvae of Phoxichilidium tubulariae (as P. femoratum) in Holland in the polyps of Tubularia. Here they do not form cysts but live freely in the gastral cavity of their host. I have found these larvae in a similar habitat at Plymouth from spring to autumn. The Tubularia generally dies down in autumn, but wherever it is alive larvae may be found. As many as five advanced larvae may occur in 
one polyp which, however, appears to be unharmed by them. The parasite remains in the polyp until the penultimate larval stage, when it emerges and casts its skin, the young pycnogon, with three pairs of legs and rudiments of the fourth pair, crawling about among the hydroids. The larva itself is colourless, but the intestinal fluid is a deep purple when seen by transmitted light and pink by reflected light. The newly hatched larva obtained from the parent measures $60-80 \mu$ across the body, the length being about the same. It has conspicuous chelae and proboscis, the second and third appendages being drawn out into long threads at least five times the length of the body with a small tooth-like spine not far from the base. In one Plymouth larva there was a large accessory spine on the inside of the base of the chela, apparently an unusual feature.

Obviously these two species are closely related but distinct. The third species, Phoxichilidium virescens, is very different, and, except for the ovigers, it is much more like Anoplodactylus angulatus.

\section{Phoxichilidium virescens Hodge}

(Fig. $4 a-f$ )

This species was first described by Hodge (I864) from Polperro, Cornwall. I have examined his actual specimens and also one of Norman's from Plymouth and two from Starcross, Devon, from the Norman Collection. All of these are identical with those from Plymouth collected recently from Wembury and Kingsand. In the first locality they occur abundantly on Ascophyllum growing on the Church Reefs, in the second in rock pools among corallines. In both places they usually occur with Anoplodactylus angulatus, with which species at first sight they might easily be confused.

Hodge's original description is as follows: Rostrum stout, slightly thickened in the middle, truncate at the apex. Foot jaws slender and closely approximate at their origin, with 6-8 teeth. Legs moderately long. Colour pea green. Length $\frac{7}{100}$ in. He remarks that 'this species might at first be mistaken for Phoxichilidium olivaceum (Gosse); but the closely approximated foot jaws at once show its distinct character'. Gosse (I855), however, never described $P$. olivaceum, but figured it in such a way that it cannot certainly be recognized. It is probable that he had either this species or Anoplodactylus angulatus. Hoek (I88I) records and figures Phoxichilidium virescens from Holland, but it is evident that he was dealing with Anoplodactylus angulatus for, besides the evidence of his figures, he states that he found a male of this species, which he lost, which had six segments in the oviger. Grube (1872) records Phoxichilidium virescens from Brittany and Bouvier (1923) from Cette. There are no good figures of it.

$P$. virescens measures about $\mathrm{I} \mathrm{mm}$. in length. It is usually described as pea green, but in the Plymouth specimens the animal itself is a dull greenish with the intestinal fluid bright green. Usually there are dark purple bands on the body and legs. Norman (1908) remarks that his specimens from 
Starcross were still bright green after being kept for some years. These I have examined and they are still a uniform pale bright green. The body is completely segmented, the legs fairly slender, but having the same proportions and armature as $P$. robustum Dohrn. The body segments are broad and the spaces between the lateral processes narrow. The ocular process is extremely blunt and the cephalon broad. The abdomen is a short rounded knob, reaching obliquely slightly beyond the very short last lateral processes. The proboscis is bluntly truncate, showing signs of angles at the corners. There are no protuberances on the lateral processes. The chelae are armed with teeth.
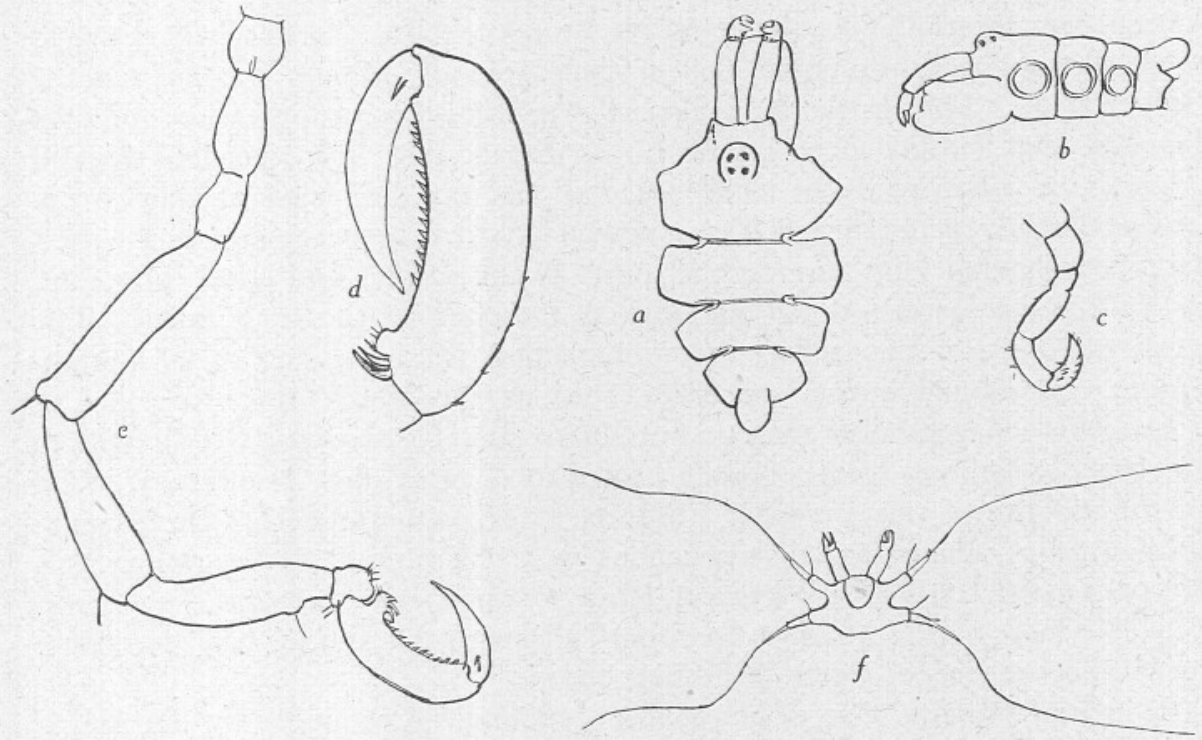

Fig. 4. Phoxichilidium virescens. $a$, dorsal view; $b$, side view; $c$, oviger; $d$, propodus; $e$, leg; $f$, newly hatched larva.

The legs have few setae, but a conspicuous seta mounted on a knob occurs distally on the femur and second tibia, a less conspicuous one on the first tibia. The second coxal segment is slightly longer than the third and the first is the shortest. The femur and tibiae are subequal. The propodus is armed with two or three, usually two, large spines at the base and a row of teeth on the sole. There is no cutting lamina. There are small auxiliary claws placed laterally. The ovigers have five segments, the last being flat and pointed and bearing two rows of reflected simple thorn-like spines. The second segment is slightly longer than the first, the third about twice as long as the second, and the fourth and fifth subequal. Very inconspicuous cement glands open by pores on the dorsal surface of the femur. Except for the very robust form and the distinct angles of the proboscis with an indentation behind the angles in $P$. robustum the characters of $P$. virescens and $P$. robustum agree in almost every particular. 
Males of $P$. virescens carrying pink eggs were obtained from September to January, but probably breeding takes place also in spring and summer. The larvae hatched out, but the host was not discovered.

$P$. virescens is common at Millport between tide-marks, and it is almost certain that the larvae described by Dogiel (I9I3) as Anoplodactylus petiolatus belonged to this species. They occurred in Syncoryne eximia in which they inhabited cysts in much the same way as Phoxichilidium femoratum, and, as he remarks, were with difficulty distinguished from these. As the larva of Anoplodactylus petiolatus has already been found in the manubrium of Obelia medusae and similar forms (Lebour, I9I7), it seems improbable that Dogiel's species was correctly identified, and his figures of the last larva newly emerged from the cyst are quite unlike that of Anoplodactylus petiolatus as are also the earlier stages. This last larva so closely resembles the form of Phoxichilidium virescens that I think there can be no further doubt. Moreover, the eggs of $P$. virescens when ready to hatch are pink and not colourless as they are in Anoplodactylus petiolatus, and the newly hatched larvae resemble Dogiel's figures in having long hairs at the joints of the second and third limbs and a small spine farther along the limb at the base of the long thread. The squarish body of the larva is very characteristic, measuring ca. $0.06 \mathrm{~mm}$. across. As Dogiel himself observes, this larva is much more like that of Phoxichilidium femoratum than that of Anoplodactylus pygmaeus. He describes the latter, which is a species closely related to $A$. petiolatus. As a further proof of the identity of this larva $\mathrm{Mr}$ Elmhirst has kindly searched in the original locality from which Dogiel's specimens were taken, and the specimens collected consisted only of $A$.pygmaeus, Phoxichilidium femoratum and $P$. virescens. No Anoplodactylus petiolatus were found, although this species has been taken at Millport in deeper water (Elmhirst, I9II).

It is unfortunate that none of the specimens examined by Dogiel is available, but it may now, I think, be taken as correct that Dogiel's larvae from Millport which he named Anoplodactylus petiolatus were really Phoxichilidium virescens, and that his Anoplodactylus pygmaeus is correcty named and is synonymous with Phoxichilidium exiguum Dohrn.

An interesting point arises from Giltay's work (1928). He notes as a distinguishing character between Phoxichilidium and Anoplodactylus the position of the auxiliary claws-placed dorsally in the former and laterally in the latter. In Phoxichilidium femoratum and $P$. tubulariae they are dorsal and are well developed, whereas in $P$. virescens they are placed laterally and are very small, very much the same size as in Anoplodactylus petiolatus and $A$. angulatus. In A. pygmaeus they are absent altogether. In Phoxichilidium australe Hodgson and certain species of Anoplodactylus described by Calman mentioned above they are also small and lateral. Here, then, is another character which demonstrates the close linkage of the two genera and the intermediate feature in Phoxichilidium virescens and Anoplodactylus angulatus. 


\section{Phoxichilidium robustum Dohrn}

This species, if indeed it be distinct from $P$. virescens, is not to be regarded as a member of the British fauna, since no specimens precisely resembling it have yet been found in British waters. I have, however, examined a specimen from the Norman Collection actually sent by Dohrn himself from Naples which is so like $P$. virescens that it is quite possible it should be regarded as a variety only. The two species are here kept apart because the more stumpy figure and distinctly angular proboscis of the Naples species does distinguish it. It is particularly interesting to find that in Norman's specimen of $P$. robustum from Naples the segmentation of the body is complete, whereas in Dohrn's description and figures there is no segmentation at all. Marcus (1940), who records and figures P. robustum (as Halosoma) from Brazil, describes his species as having the body segmented except for the last suture. In $P$. virescens the body is completely segmented. Marcus's figure is even more like $P$. virescens, and a figure of a leg by Giltay (1929) of $P$. robustum from Belgium is not nearly so robust as the original robustum although he describes the body as being non-segmented and the proboscis angular. The segmentation or otherwise of the body thus appears to be a variable feature, and the amount of compression of the segments apparently goes with it.

In the $P$. robustum described and figured by Dohrn the body is very much compressed and non-segmented, the legs plump and compact, and the proboscis with distinct angles, the surface below the angles indented. In the Norman specimens from Naples the body is segmented, but otherwise like the description and figures of Dohrn. Unfortunately, it is a female, but Dohrn's figures of the male show the ovigers of five segments and the proportions similar to Marcus's $P$. robustum. The latter is not quite so stumpy as Dohrn's specimen, and in $P$. virescens we have a fully segmented body, not quite. so thick as $P$. robustum, with more slender legs, the ovigers being similar and also the armature of the legs, but the proboscis less angular. In all three the ocular process is very short and the abdomen short and rounded. They are so alike that it is impossible to place them in separate genera, and as is shown it is not certain that virescens and robustum are distinct species.

Many recent authors have removed P. robustum from Anoplodactylus and placed it in Phoxichilidium, but several have placed it in the genus Halosoma (regarded as a subgenus of Anoplodactylus by Loman (1908)). At the same time they place Phoxichilidium virescens either in Phoxichilidium, which is correct (Marcus, $1940^{1}$ ), or in Anoplodactylus, which is wrong (Norman, 1908; Bouvier, 1923) if we go by the ovigers. That is to say, the majority of workers place Phoxichilidium virescens and P. robustum in different genera, which is certainly wrong, as they resemble one another so closely.

1 Marcus was, however, really dealing with Anoplodactylus angulatus as he refers to Hoek's species. 


\section{Genus Anoplodactylus Wilson}

Bouvier (1923) admits seven species from France in the present genus. Except for $A$. massiliensis these are all found at Plymouth, but the number must be reduced to three ( $A$. petiolatus, $A$. pygmaeus and $A$. angulatus). As will be shown below, $A$. pygmaeus and $A$. exiguus are synonymous, and it has already been shown that $A$. virescens and $A$. robustus belong to Phoxichilidium.

There has always been difficulty over Anoplodactylus pygmaeus. Many workers, including myself (I9I7), following Norman (I894, I908), regarded it as synonymous with $A$. petiolatus, possibly the young of that species. The prevailing opinion now is that it is distinct, which is certainly correct (Wiren, I9I8; Carpenter, I905; Giltay, I928; Schlottke, I932, etc.). Norman (I908) gives a long list of species which he regards as synonyms of $A$. petiolatus and before this (I894) states his reasons for regarding $A$. pygmaeus as probably the young of $A$. petiolatus. Having now found adults of both species at Plymouth, including males bearing eggs, I am certain that they are separate species.

Among the misconceptions which have arisen the first is that many workers have regarded Hoek's Phoxichilidium pygmaeus as synonymous with Hodge's Pallene pygmaeus, and not, as it undoubtedly is, with Anoplodactylus petiolatus, while, secondly, many have followed Norman in placing Dohrn's Phoxichilidium exiguum in the synonymy of Anoplodactylus petiolatus. Norman's list of synonyms of $A$. petiolatus, which includes Hoek's Phoxichilidium pygmaeus, is apparently right except for the inclusion of Hodge's Pallene pygmaeus and Dohrn's Phoxichilidium exiguum. These two, as will be shown below, are synonymous and quite distinct from Anoplodactylus petiolatus. Bouvier (I923), on the other hand, recognizes too many species and places Phoxichilidium exiguum (as Anoplodactylus) far away from pygmaeus, whilst the latter species he regards as closely related to $A$. petiolatus. His description and figures of pygmaeus are, however, taken from Hoek's form and actually represent $A$. petiolatus.

Having found at Plymouth a very large number of the small species which is the Pallene pygmaeus of Hodge (I864) and the P. pygmaeus of Dogiel (I9I3) from Millport (the larvae of which he describes), it was found that they correspond in every way with Dohrn's Phoxichilidium exiguum (I88I). That they were synonymous was first noted by Norman (I894), who actually compared Hodge's type specimen from the Hancock Museum, Newcastle-upon-Tyne, with specimens of $P$. exiguum sent by Dohrn from Naples. Hodge's type specimen, unfortunately, cannot be found, but I have examined Dohrn's specimens from the Norman Collection, which are the same as the Plymouth and Millport species. Norman was wrong in supposing them to be the young of $A$. petiolatus, but this important observation as to their identity appears to have been overlooked by later workers who have continued to regard them as separate species, even sometimes placing them in different genera (Helfer 
\& Schlottke, I935; Marcus, I940). It can now be established that $A$. petiolatus and $A$. pygmaeus are separate but closely related species, and that $A$. exiguus is a synonym of $A$. pygmaeus.

The number of British species is thus reduced to three, excluding $A$. oculatus and $A$. typhlops dredged by Carpenter (I905) in deep water off the Irish coast. Of these three, $A$. petiolatus, $A$. pygmaeus and $A$. angulatus, the first two may be regarded as typical Anoplodactylus, with a more or less elongated ocular process, cement glands opening in a funnel on the femur, the propodus armed with a cutting plate and having protuberances on the lateral processes, whilst $A$. angulatus has a very short ocular peduncle, no funnel for the cement glands, no cutting plate on the propodus, and no protuberances on the lateral processes. A. angulatus thus links Anoplodactylus with Phoxichilidium.

\section{Anoplodactylus angulatus (Dohrn)}

(Fig. $5 a-f$ )

Phoxichilidium angulatum Dohrn, I88I.

$P$. virescens Hodge, Hoek, I88I.

Anoplodactylus angulatus (Dohrn) Bouvier, I923.

This species is now added to the British fauna for the first time. At first sight it is so like Phoxichilidium virescens that it may well have been confused with that species. It does not, however, appear to occur with $P$. virescens at Millport, although the two are commonly found together at Plymouth, both on Ascophyllum and among corallines at Wembury and at Kingsand. They also occur in the Laira dredgings. Both were specially common among short Sertularia on the Ascophyllum at Wembury.

The species was first discovered at Naples by Dohrn and is recorded by Bouvier from Cette and by Giltay from Banyuls. Hoek's Phoxichilidium virescens from Herdla must be this species, as he mentions that there were six segments in the oviger of a male. A specimen from Naples, sent by Dohrn, which is in the Dundee collection, is undoubtedly the same as the Plymouth species. The very sharp angles on the proboscis distinguish it at once from $P$. virescens, but except for the ovigers (with six segments in $P$. angulatus, but only five in $P$. virescens) the species comes so near to $P$. virescens that it appears really to be more closely related to it than to Anoplodactylus petiolatus and Phoxichilidium pygmaeus. Both Norman (I908) and Bouvier (I923) knew this and regarded them both as belonging to Anoplodactylus, neither of them having apparently observed the differences in the ovigers.

Dohrn gives the length of the body as $\mathrm{I} \cdot 5^{-2} \mathrm{~mm}$. The Plymouth specimens are usually smaller and adults may be $0.96-\mathrm{I} \cdot 3 \mathrm{~mm}$. in length. The first body segment is broad, the second and third of moderate size, but the last is very much smaller with the lateral processes reduced to mere stumps. There are no protuberances on the lateral processes. The body in the Plymouth specimen is completely segmented, although Dohrn states that segmentation is absent between the third and fourth segments. In the specimens from Naples in 
the Dundee collection it was not possible to be certain on this point owing to its bad preservation. The cephalon is short and broad and bears a short rounded ocular tubercle slightly pointed at the tip which does not overlap the anterior margin of the cephalon. The abdomen is more than twice the length of the last lateral processes. The proboscis is stout, cylindrical, with conspicuous angles anteriorly. The spaces between the lateral processes are narrow but distinct. The legs are fairly long but stout, with long setae as
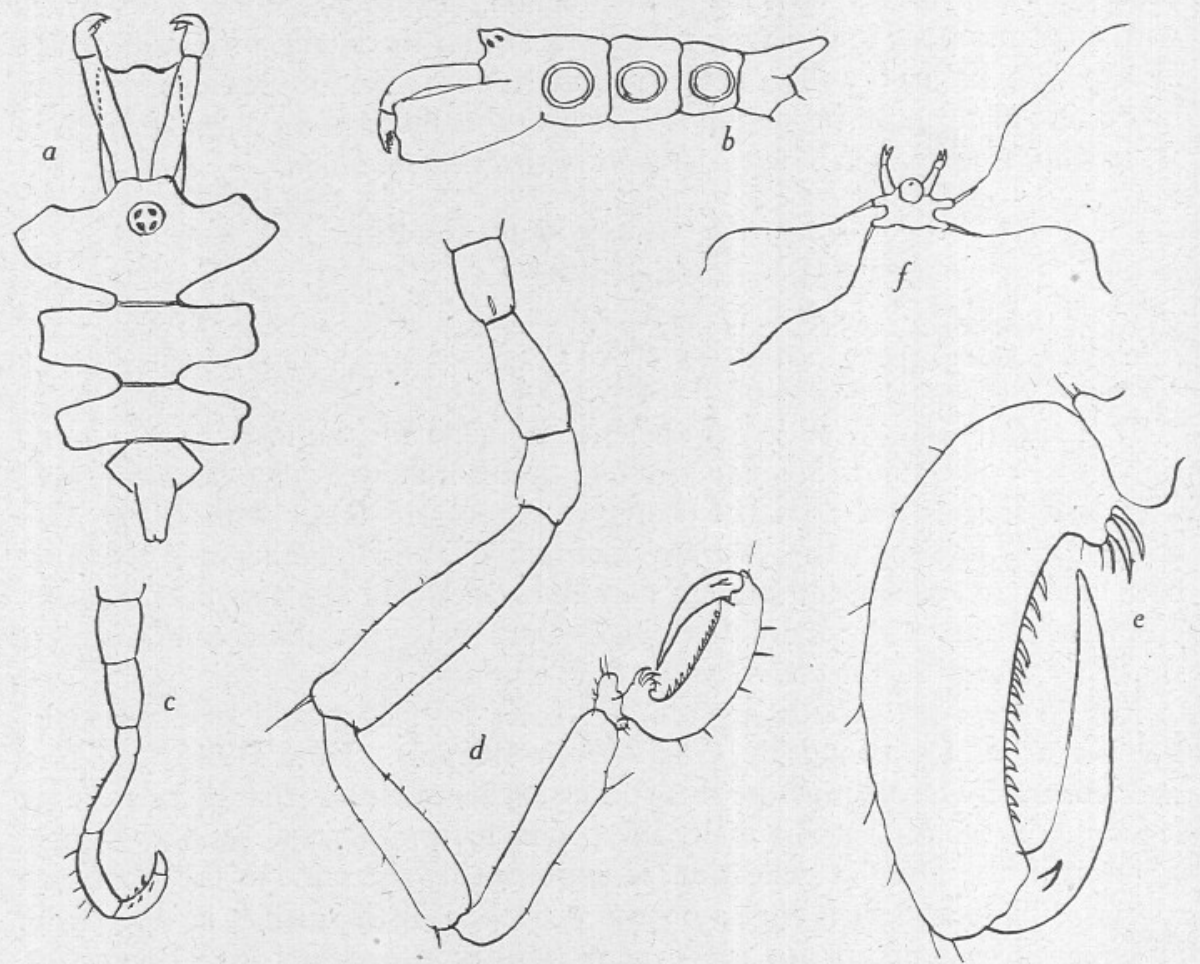

Fig. 5. Anoplodactylus angulatus. $a$, dorsal view; $b$, side view; $c$, oviger of $\delta ; d$, leg; $e$, propodus; $f$, newly hatched larva.

in Phoxichilidium virescens, but without such distinct knobs. The chelae, which are toothed as in $P$. virescens, project well beyond the proboscis. The cement glands are situated on the femur as in $P$. virescens, but are very inconspicuous. The ovigers are shaped like those of $P$. virescens with the end pointed, but have six segments instead of five. The second segment is nearly double the length of the first and about two-thirds the length of the third, the fourth slightly shorter than the third, the fifth and sixth flattened and together slightly shorter than the fourth. The fifth bears two rows of tooth-like recurved spines as in $P$. virescens. The propodus is armed with two large teeth and three setae preceding a row of teeth on the sole. There is no lamina. There 
are small auxiliary claws. The whole propodus is like $P$. virescens. Norman (1908) notes in his Naples specimen that there is a swelling at the base of the claw only to be seen when it is extended. This is sometimes, but not always, to be seen in the Plymouth specimen. It is usually not so pronounced as in Norman's figure. A trace of it is sometimes seen also in $P$. virescens.

Males carrying eggs were found in summer and autumn and larvae hatched out. It was not possible to rear them as the host was not ascertained. It is probable that the host is the Sertularia amongst which they lived on the Ascophyllum, but attempts to persuade the larvae to enter the hydroid were unsuccessful. The larva is like that of Phoxichilidium tubulariae, but smaller and with shorter appendages, and no teeth or hairs were visible at the base of the flagelliform threads. Eyes were present in these newly hatched larvae.

It is interesting to note that Marcus (1940) shows hairs on the legs in his Anoplodactylus carvalhoi and A. strictus which are similar to those in Phoxichilidium virescens.

In Anoplodactylus angulatus we have an Anoplodactylus which through Phoxichilidium virescens is closely related to Phoxichilidium proper as represented by $P$. femoratum and $P$. tubulariae.

\section{Anoplodactylus petiolatus (Krøyer)}

(Fig. $6 a-h)$

Phoxichilidium petiolatum Krøyer, I844.

Pallene attenuata Hodge, 1864.

Phoxichilidium petiolatum Krøyer, Hodge, 1864.

P. longicolle Dohrn, I88I.

$P$. pygmaeum (Hodge) Hoek, r88r.

Anoplodactylus petiolatus (Krøyer) Sars, I89r.

A. petiolatus (Krøyer) Bouvier, I923.

Anaphia petiolata (Krøyer) Norman, 1908 (in part).

A. petiolata (Krøyer) Lebour, I9I7.

Anoplodactylus pygmaeus (Hodge) Bouvier, 1923.

This well-known species occurs fairly commonly at Plymouth, but is never found in numbers. Its larva, however, is abundant in late spring and in summer in the manubrium of Obelia medusae and related forms in the plankton. It has already been recorded from Plymouth Sound by Norman (1908) and from Asia Shoal and Winter Shoal in Plymouth Marine Fauna (193I). Recently, I have found it in tangles of Bowerbankia and hydroids dredged from the Laira. Males with eggs were found in August and September I944, and without eggs in October I944. The young larvae have not yet been seen and, as shown above, Dogiel's larvae from Millport, which occurred in cysts in Syncoryne, are almost certainly Phoxichilidium virescens. The adult has been recorded from Millport (Elmhirst, I9II and by Norman, I908), but dredged in fairly deep water.

Dogiel (I9II) states that he found this species at Cullercoats and followed its life history, the larvae inhabiting the polyps of Campanularia flexuosa 
(Hincks). He remarks that the larvae 'were characterized by the uncommonly strong development of the last joint of the second and third pair of legs, and by the complete absence of eyes. The way in which the larvae enter the polyps was observed and the duration of the parasitic stage was found to be from 8 to I2 days. After this period the larva moults and leaves its host.' This account differs very much from his Millport observations and indicates still more strongly that he was dealing with different species. Unfortunately, no trace of the Cullercoats specimens can be found, and apparently these observations were not published in any more detail.
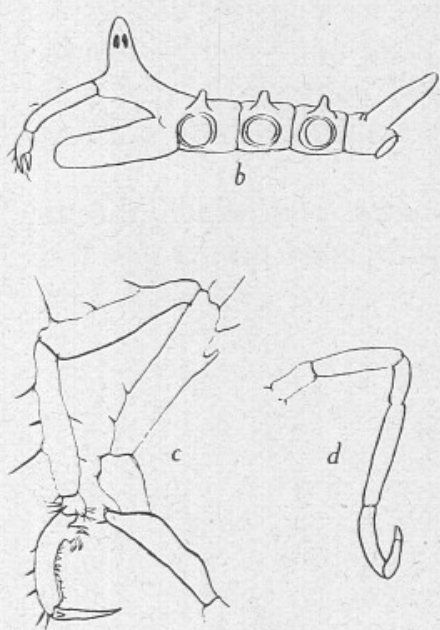
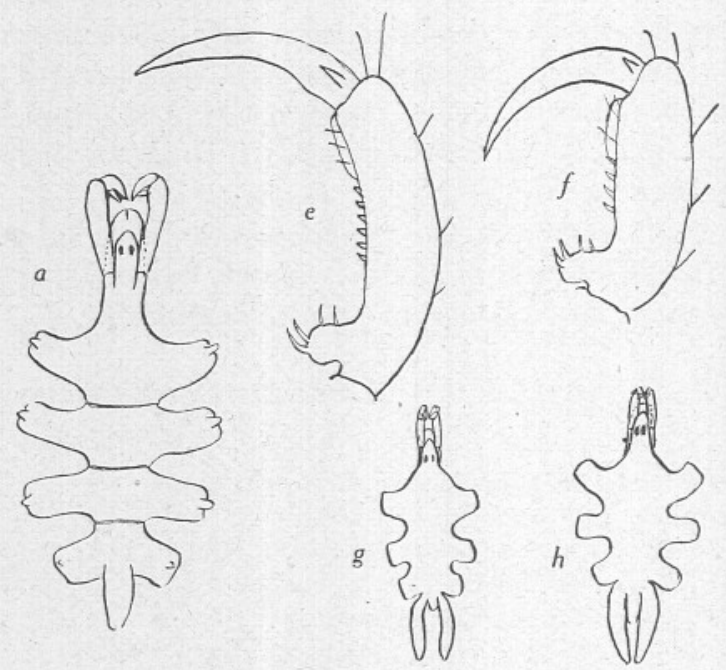

Fig. 6. Anoplodactylus petiolatus. a, dorsal view; $b$, side view; $c$, leg of $\hat{o} ; d$, oviger of $\hat{b} ;$ $e$, propodus of adult; $f$, propodus of young form; $g$, last larval stage escaped from medusa; $h$, last larval stage a few days old.

The Plymouth specimens from the Laira agree exactly with the excellent descriptions and figures of Sars (I89I) which are copied in nearly all recent works. They also agree with Dohrn's Phoxichilidium longicolle. It is to be noted here that Dohrn does not figure the protuberances on the lateral processes, except for a trace in the main figure, but I have examined specimens sent by Dohrn from Naples in the Norman Collection, and the protuberances were quite distinct and the specimens agree exactly with those from Plymouth. This species is the Pallene attenuata of Hodge (I864), who later in the same paper corrected it to Phoxichilidium petiolatum of Krøyer.

Anoplodactylus petiolatus is very slender and all its parts are elongated. The colour is pale yellowish or it is colourless. A specimen was found with deep purple bands similar to the variety of $A$. pygmaeus. The body is $\mathrm{I} \cdot 2-\mathrm{I} \cdot 5 \mathrm{~mm}$. in length. The neck is very long, and the ocular process is long and reaches nearly to the end of the proboscis which is cylindrical and rounded at the 
end. The segmentation of the body is complete, the spaces between the lateral processes wide and rounded. There are conspicuous conical protuberances without hairs on the lateral processes. The abdomen is long and narrow, reaching well beyond the last lateral processes. In the ovigers of the male the third segment is very long, about twice the length of the second. The legs are elongated, the femur and tibiae subequal. The femur bears dorsally a conspicuous funnel for the opening of the cement glands. The propodus is armed internally with two large teeth and a smaller pair, with six teeth on the sole and a cutting lamella. In young forms, and sometimes in adults, there are only four teeth before the lamella as in Hoek's (I88I) figures of Phoxichilidium pygmaeum, which is really Anoplodactylus petiolatus, and Bouvier's (1923) figure of $A$. pygmaeus, which is taken from Hoek. The claw is long and bears small auxiliary claws placed laterally.

It has been shown (Lebour, I917) that the cephalon elongates with age and the young have a much shorter neck than the adults. This can be well seen in late larvae which have emerged from the medusae and then kept in bowls for a few days.

The distribution is wide, ranging from far north to the Mediterranean. Marcus (1940) records it, or possibly a closely related species, from Brazil.

\section{Anoplodactylus pygmaeus (Hodge)}

Pallene pygmaea Hodge, I864.

(Fig. $7 a-l$ )

Phoxichilidium exiguum Dohrn, I88I.

Anoplodactylus pygmaeus (Hodge) Dogiel, I913, larvae.

? Anoplodactylus pygmaeus (Hodge) Giltay, I928.

Anoplodactylus exiguus (Dohrn) Bouvier, 1923.

A. pygmaeus (Hodge) Schlottke, 1932.

This species was first discovered by Spence Bate at Plymouth; he notices it in the British Association Report, Hull, I853, and remarks on the larvae, but neither describes nor figures it. Hodge (I864) describes it and records it from the Durham coast. It is not the species described and figured by Hoek (I88I) from Holland as Phoxichilidium pygmaeum, which, as Norman (1894, 1908) has rightly maintained, is Anoplodactylus petiolatus. It is, however, the species whose larvae are described by Dogiel (1913) in hydroids of Obelia from Millport; in this locality it appears to be common, and I have made a careful examination of specimens kindly sent to me by Mr Elmhirst. Phoxichilidium exiguum described and very accurately figured by Dohrn is also synonymous with this species.

Anoplodactylus pygmaeus occurs abundantly at Plymouth, in tufts of Bowerbankia and hydroids from Phoenix Wharf, in tufts of the same dredged from the Laira, on the Church Reefs at Wembury between tide-marks among corallines and hydroids, and in rock pools at Kingsand. It is now found to be one of the commonest shallow-water forms at Plymouth. It carries eggs from spring to autumn, and larvae were hatched and reared in Obelia 
hydroids in a bowl until they emerged in the last larval stage. These larvae and their habitat in the gastral cavity of the Obelia hydroid agree exactly with Dogiel's description.

Comparing the Plymouth and Millport specimens with Dohrn's (I88I) description and figures of Phoxichilidium exiguum it is obvious that the species are identical. I have now examined specimens from Naples sent by Dohrn to Norman in the Norman Collection and confirmed this. Norman's mistake was to regard them as synonymous with Anoplodactylus petiolatus. The

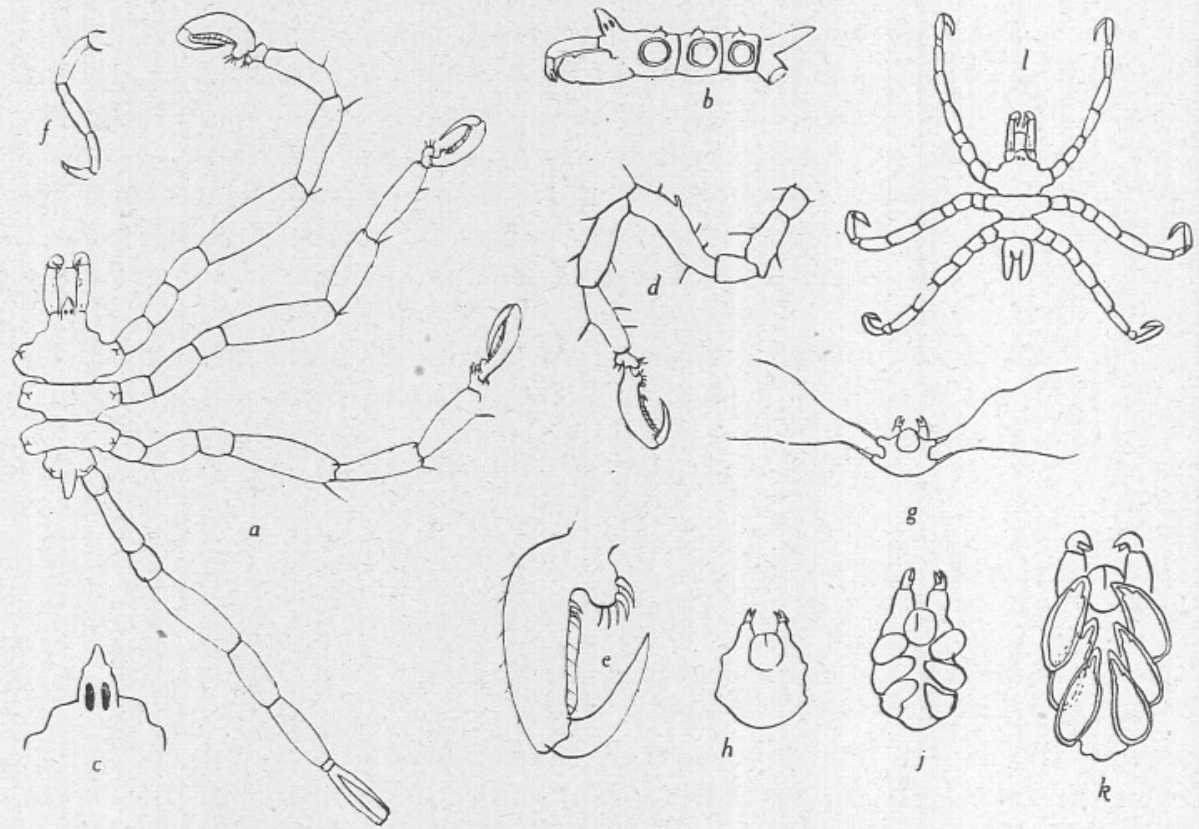

Fig. 7. Anoplodactylus pygmaeus. $a$, dorsal view; $b$, side view; $c$, ocular process; $d$, leg of ${ }^{A}$; $e$, propodus; $f$, oviger of $o^{*} ; g$, newly hatched larva; $h$, early larva in Obelia hydroid; $j$, older larva in Obelia hydroid; $k$, penultimate larva in Obelia hydroid; $l$, last larva emerged from Obelia hydroid.

A. pygmaeus (Hodge) figured and recorded from Heligoland by Schlottke (I932) is correctly named and the species is correctly placed in the key to Anoplodactylus in the Nachtrag to Die Tierwelt der Nord- und Ostsee by Helfer (1935).

A. pygmaeus is a very small species, $0.65-\mathrm{I} \mathrm{mm}$. long. Although described by Dohrn as having the last two body segments fused, all the specimens I have examined, including those from Naples, are completely segmented, the division between the last two being sometimes difficult to see. The body is also completely segmented in Schlottke's (1932) figure. There are small protuberances on the lateral processes, each tipped with a hair. The spaces between the processes are narrow, but quite distinct. The cephalon is broader 
than long, but the ocular process overlaps it well in front and is pointed at the end. The proboscis is cylindrical, rounded anteriorly, with a constriction encircling it near the front. The abdomen is about twice as long as the last lateral processes and borne slightly obliquely. The legs are fairly long, not so slender as those of $A$. petiolatus, the femur of the male having a dorsal funnel for the cement glands. The propodus is stumpy with one or two teeth before the long lamina on the inside, fine hairs supporting the latter. The claw is about the same length as the sole of the propodus and there are no auxiliary claws. Perhaps the most important character is the segmentation of the ovigers. Because of the mistaken identity of Hoek's Phoxichilidium pygmaeum (which is really Anoplodactylus petiolatus) it has been thought that the third segment was very long, about twice as long as the second as it is in A. petiolatus. In reality the oviger of pygmaeus has the third segment fairly short. It is difficult to see in Dohrn's figure of exiguum on account of the eggs, but his description is quite clear on this point. In the oviger of $A$. pygmaeus the third segment is hardly longer than the second. There are no good figures of A.pygmaeus except Dohrn's (as Phoxichilidium exiguum) which are excellent. Nearly all authorities have taken Hoek's figures as representing this species. The colour is pale straw colour or it may be colourless. A certain number, about $20 \%$ from the Bowerbankia, had dark purple stripes.

The chief differences between $A$. pygmaeus and $A$. petiolatus are summarized below:

\section{A. petiolatus}

Body elongated, $\mathrm{I} \cdot 2-2 \mathrm{~mm}$. Lateral processes large and rounded

Protuberances on lateral processes unarmed

Cephalon longer than broad

Proboscis cylindrical, without groove, rounded at apex

Oviger with third segment twice as long as the second

Propodus long and narrow, armed with 4-6 teeth before the short lamina; small auxiliary claws

Larva in Obelia medusa and related forms

\section{A. pygmaeus}

Body short, $0.65-1 \mathrm{~mm}$. Lateral processes distinct, narrow

Protuberances on lateral processes armed with a hair at apex

Cephalon broader than long

Proboscis cylindrical with circular groove near apex which is rounded and triangular

Oviger with third segment about equal to the second

Propodus short, armed with one or two teeth before the long lamina; auxiliary claws absent

Larva in gastral cavity of Obelia hydroid

Marcus (I940) records $A$. pygmaeus from Brazil. His description and figures, however, show almost certainly that it is a different species. The ocular process is much shorter and blunter; there are no protuberances on the lateral processes, and the third segment of the oviger is much longer than in $A$. pygmaeus. The absence of auxiliary claws and the armature of the propodus, together with the funnel for the cement glands, show it to be closely related. 
A. pygmaeus, as described by Dogiel (I9I3), feeds on and breeds in Obelia, the larva inhabiting the gastral cavity of the hydroid until it emerges in the last stage with three pairs of legs and rudiments of the last pair. I have hatched out the larvae at Plymouth, and by placing them on Obelia hydroids found them penetrating the polyps and growing inside them exactly as described by Dogiel. The larva is pale yellowish, and in the later stages is slightly smaller than those of Anoplodactylus petiolatus from the medusae, although in form it is much the same. There are no eyes, as Dogiel has already noted, whereas eyes are present in the later larvae of $A$. petiolatus. The last larval stage which emerges from the polyp is quite distinct from that of $A$. petiolatus, being smaller, with a much broader and shorter cephalon and much shorter legs. The length of the last larva, newly emerged from the Obelia polyp, is $0.4 \mathrm{~mm}$.; that of Anoplodactylus petiolatus, newly emerged from the medusa, is $0.64 \mathrm{~mm}$., and in each the spaces between the lateral processes show the features of the adult.

Dohrn (I88I) has classified the Phoxichilidiidae by the form of the proboscis and the nature of the cement glands, thus separating $A$. petiolatus and exiguum (pygmaeus) from $A$. angulatus and Phoxichilidium robustum, which seems to be natural.

A key to the British Phoxichilidiidae including both Phoxichilidium and Anoplodactylus is given below:

I. Ocular process not projecting beyond cephalon. No funnel for cement glands. No protuberances on lateral processes. Propodus without cutting lamina.

A. Ovigers with five segments.

AA. Proboscis straight at end with more or less distinct angles at corners. Body and legs compact. Auxiliary claws small and placed laterally.

\section{Phoxichilidium virescens}

AAA. Proboscis rounded at end without angles. Body and legs elongated. Auxiliary claws fairly large and placed dorsally.

a. Abdomen twice as long as last lateral processes. Proboscis wider anteriorly.

Phoxichilidium tubulariae

$b$. Abdomen hardly as long as last lateral processes. Proboscis cylindrical. Phoxichilidium femoratum

B. Ovigers with six segments. Auxiliary claws small and placed laterally. Anoplodactylus angulatus

II. Ocular process projecting beyond cephalon. Cement glands opening in funnel on femur. Protuberances on lateral processes. Propodus with cutting lamella. Ovigers with six segments.

A. Cephalon longer than broad, auxiliary claws small, placed laterally. Anoplodactylus petiolatus

B. Cephalon broader than long. No auxiliary claws. Anoplodactylus pygmaeus 


\section{Family PHOXICHILAE}

Genus Endeis

Endeis spinosus (Montagu)

This species is fairly common round Plymouth. One male with eggs found in July I94I and one in January 1945 (for detailed records see Plymouth Marine Fauna, 193I). Young not fully developed were found clinging to medusae in the plankton, and larvae were found in Obelia hydroids (Lebour, I917). The species occasionally to be found between tide-marks on the Church Reefs, Wembury, on the Millbay Pontoon, and in Laira dredgings.

A widely distributed species, inhabiting both shallow and deep water, ranging from Norway to the Azores and Mediterranean, north and south Atlantic coasts of America and the Sargasso Sea.

\section{Family AMMOTHEIDAE \\ Genus Ammothea Ammothea echinata (Hodge)}

This is a very common species, found in Bowerbankia from Phoenix Wharf, Wembury and Kingsand and dredged in the Sound (for detailed records see Plymouth Marine Fauna, 193I). The species breeds in spring and summer.

A widely distributed species, ranging from Norway to the Mediterranean, Azores and Atlantic coast of America.

\section{Ammothea longipes (Hodge) \\ Achelia hispida Hodge, 1864}

Norman (1908) records this species from Starcross, Devon, but I cannot find any early records from Plymouth. It is fairly common with $A$. echinata between tide-marks both at Wembury and Kingsand and has also been found at Phoenix Wharf in Bowerbankia.

It is not nearly so plentiful as $A$. echinata.

Recorded from Naples and the coasts of Brittany.

$$
\text { Ammothea laevis (Hodge) }
$$

This species is recorded by Hodgson (I9I0) from the Eddystone Grounds, but I have not seen it and can find no further records from Plymouth.

It usually occurs from below low water to $40-60 \mathrm{~m}$. and is recorded from Norway, north-west France and Belgium.

\section{Family PYCNOGONIDAE \\ Genus Pycnogonum \\ Pycnogonum littorale (Ström)}

This species is usually found below low-water mark. A dead specimen occurred high up on the Church Reefs, Wembury, among Ascophyllum. For details of records see Plymouth Marine Fauna (I93I). 
A widely distributed species from tidal zone to a depth of $800 \mathrm{~m}$. It is recorded from Iceland and Greenland to the west coast of France, Mediterranean, northern Atlantic and the east coast of the United States.

\section{REFERENCES}

Bouvier, E. L., I923. Faune de France, 7, Pycnogonides, pp. I-68.

Calman, W. T., I915. Pycnogonida. British Antarctic ('Terra Nova') Expedition, I9ro, Zool., Vol. III, pp. I-74.

- I923. Pycnogonida of the Indian Museum. Rec. Ind. Mus., Vol. xxv, pp. 265-99.

Carpenter, G. H., I905. The marine fauna of the coast of Ireland. Part VI. Pycnogonida. Rep. Fish. (Ireland) Sci. Inv. Dublin, Vol, 4, pp. I7I-8.

Cole, L. J., 1904. Pycnogonida of the west coast of North America. Harriman Alaska Expedition, Vol. x, pp. 249-98.

Colman, J., I940. On the faunas inhabiting intertidal seaweeds. Fourn. Mar. Biol. Assoc., Vol. xxiv, pp. I29-83.

Crawshay, L. R., rgi2. On the fauna of the English Channel. Fourn. Mar. Biol. Assoc., Vol. IX, p. 292.

DogIel, V., I9Ir. A short account of work on Pycnogonida done during June, I9I I, at Cullercoats. Northumberland Sea Fish. Comm. Rep. Sci. Inv., pp. 26-7.

- I9I3. Embryologische Studien an Pantopoden. Zeitschr.f. wiss. Zool., Bd. I07, pp. $576-74 \mathrm{I}$.

Dohrn, A., I881. Die Pantopoden des Golfes von Neapel, pp. I-252. Leipzig.

ElmhIrst, R., I9I I. List of Pycnogonida collected in the Clyde Area. Trans. Nat. Hist. Soc. Glasgow, Vol. 8, pp. I46-9.

Giltay, L., I928. Notes sur les Pycnogonides de la Belgique. Bull. Ann. Soc. ent. Belg., T. 68, pp. 193-229.

- 1929. Quelques Pycnogonides des environs de Banyuls (France). Bull. Ann. Soc. ent. Belg., T. 69, pp. 172-6.

Gosse, P. H., 1855. A Manual of Marine Zoology for the British Isles. Part I.

Helfer, H., I926. Die Tierwelt der Nord- und Ostsee. Lief. xxxI, Teil xI. a. 3. Pantopoda (2. Nachtrag), pp. I-5.

Helfer, H. \& SchlotTke, E., 1935. Pantopoda in Bronn's Klassen und Ordnungen des Tierreichs. Bd. 5, Abt. Iv, Buch 2, pp. I-3I4.

Hodge, G., I86I. Observations on a species of Pycnogon (Phoxichilidium coccineum Johnston) with an attempt to explain the order of its development. Trans. Tyneside Nat. Fld. Clb., Vol. v, pp. 124-36. (Also in Ann. Mag. Nat. Hist. I862, Ser. 3, Vol. IX, pp. 33-43.)

- I863. Report on the Pycnogonoidea, with description of two new species. Trans. Tyneside Nat. Fld. Clb., Vol. v, pp. 281-3. (Also in Ann. Mag. Nat. Hist., I863, Ser. 3, Vol. xI, p. 463.)

I 1864 . List of the British Pycnogonoidea with description of several new species. Ann. Mag. Nat. Hist., Ser. 3, Vol. xiII, pp. II3-I7.

Hodgson, T. V., I9Io. The Pycnogonida of Devonshire. Trans. Devon. Ass. for the Advanc. of Sci. Lit. and Arts, Vol. XLII, pp. 425-39.

Hoek, P. P. C., 1881. Nouvelles études sur les Pycnogonides. Arch. Zool. Exp. et Gén.; T. IX, pp. 445-542.

Lebour, M. V., I9I7. Notes on the life history of Anaphia petiolata (Krøyer). Fourn. Mar. Biol. Assoc., Vol. XI, pp. 5I-6. 
Loman, J. C. C., 1907. Biologische Beobachtungen an einem Pantopoden. Tijd. Ned. Dierk. Ver., Ser. 2, Bd. I0, pp. 225-84.

I908. Die Pantopoden der Siboga Expedition. Leiden.

Marcus, E., I940. Os Pantopoda brasilieros e os demais sul-americanos. Boll. da Faculd. de filos-ciencias e letras, Vol. XIX, pp. I-I4I.

Norman, A. M., I894. A month on the Trondhjem Fiord. Ann. Mag. Nat. Hist., Ser. 6, Vol. 13, pp. 150-64.

I908. The Podosomata (Pycnogonida) of the Temperate Atlantic and Arctic Oceans. Linn. Soc. Fourn. Zool., Vol. xxx, pp. 198-238.

Plymouth Marine Fauna, Ist ed. 1904, 2nd ed. 1931. Marine Biological Association.

SARS, G. O., I891. Pycnogonidea. The Norwegian North Atlantic Expedition -1876I878. Christiania, pp. I-I63.

Schlottke, E., 1932. Die Pantopoden der deutschen Küsten. Wiss. Meeresunters. (N.F.) Abt. Helgoland. Bd. I8, Hft. 3, Abh. 9, pp. I-Io.

WILson, E. B., 1878. Description of two new genera of Pycnogonida. Amer. Fourn. Sci. \& Art., Ser. 3, Vol. 15, pp. 200-3.

Wiren, E., I9I8. Zur Morphologie und Phylogenie der Pantopoden. Zool. Bid. frain Uppsala, Bd. 6, pp. 42-I8I. 